\title{
Przejawy grzeczności językowej $w$ medialnych rozmowach ze sportowcami
}

\author{
Features of Verbal Politeness in Media Conversations \\ with Athletes
}

\begin{abstract}
This article discusses features of verbal politeness occurring in three different types of the media interviews with athletes: standard interviews (on the radio), interviews typical of sports journalism (post-event micro-interviews), and the most recent forms of communication with athletes (interviews on the Internet). The research, which involved using the pragmalinguistic methodology and the linguistic-communicative approach, confirms that the participants of this type of interactions strive for cooperation and use Polish strategies of verbal politeness. The analysis has identified three groups of features of verbal politeness: phrases related to elementary politeness, phrases related to formal etiquette, and polite speech formulas.
\end{abstract}

Key words: verbal politeness, elementary politeness, formal etiquette, media conversation, sports journalism

\begin{abstract}
Abstrakt: Przedmiotem opracowania są językowe zachowania grzecznościowe występujące w trzech odmianach medialnych rozmów ze sportowcami: dialogach w postaci klasycznej (wywiadach radiowych), rozmowach typowych dla dziennikarstwa sportowego (mikrowywiadach pomeczowych) i najnowszych formach komunikacji z zawodnikami (wywiadach internetowych). Badania, w których wykorzystano metodologię pragmalingwistyczną i ujęcie językowokomunikacyjne, potwierdzają, że uczestnicy tego typu interakcji dążą do kooperacji i realizują polskie strategie grzecznościowe. Rezultatem analiz jest wyodrębnienie trzech grup przejawów grzeczności językowej w medialnych rozmowach ze sportowcami: zwrotów związanych z grzecznością elementarną, zurotów związanych z grzecznością elitarną oraz grzecznościowej obudowy wypowiedzi.
\end{abstract}

Słowa klucze: grzeczność językowa, grzeczność elementarna, grzeczność elitarna, rozmowa medialna, dziennikarstwo sportowe

\section{Wprowadzenie}

Grzeczność językowa stanowi jeden z najważniejszych czynników, które wpływają na kontakt między nadawcą a odbiorcą i decydują o powodzeniu komunikacji. Małgorzata MARCJANIK definiuje ją jako „zbiór przyjętych w danej społeczności wzorów językowych zachowań grzecznościowych, zwyczajowo przyporządkowanych określonym sytuacjom pragmatycznym" (2007: 12) i nazywa „społecznie akceptowaną grą, w którą "gramy z innymi członkami grup społecznych przez całe życie" (2017: 6). W pracach naukowych grzeczność jest często postrzegana wieloaspektowo - przede wszystkim jako wzorzec społeczny 
pożądany w kontaktach międzyludzkich (por. np. Anusiewicz, Marcjanik, red., 1992: 7; SKUDRZYK, 2007: 105; KıтA, 2016: 194). Językowe zachowania grzecznościowe są bowiem istotnym składnikiem partnerstwa komunikacyjnego, czyli relacji opierającej się na współpracy między interlokutorami. Wymiana formuł grzecznościowych, takich jak powitania, pozdrowienia czy komplementy, wytwarza specyficzną aurę $w$ czasie interakcji, która przez filozofów języka nazywana jest „atmosferą grzeczności”1 (GrodzıŃskı, 1980: 90). To, czy uczestnik aktu komunikacji zna zasady grzecznościowe i stosuje się do nich, czy przejawia zainteresowanie drugim człowiekiem i jego sprawami, czy poprzez stosowanie adekwatnych do sytuacji zurotów okazuje szacunek partnerowi dialogu, ma fundamentalne znaczenie $w$ komunikacji, także $w$ przestrzeni medialnej.

\section{Rozmowa medialna}

Gatunkiem wypowiedzi $w$ mediach, $w$ którym aspekt pragmatyczny, a w szczególności wszelkie przejawy grzeczności językowej pełnią istotną funkcję, jest rozmowa medialna. We współczesnej sferze medialnej zauważa się wiele form opierających się na wymianie werbalnej - warto wspomnieć między innymi o wywiadzie (por. KıтA, 1998; Sовсzак, 2006), radiowych formach gatunkotwórczych o charakterze rozrywkowym takich jak talk-joke, phone-in oraz game show (por. STACHYRA, 2008), telewizyjnym programie talk show (por. PTASZEK, 2007) czy internetowych rozmowach prowadzonych $w$ ramach działalności wideoblogowej (por. KACPERSKA, 2020). Ekspansję wypowiedzi w mediach wykorzystujących dialogowość Małgorzata KıтA nazywa „współczesnym fenomenem medialnym” i „medialną modą na dialog" (2012: 19). Przyczyn takiego zjawiska można upatrywać w podstawowych właściwościach rozmowy medialnej, która jest typem wywiadu ściśle związanym z dialogowymi formami o znamionach potoczności - oprócz struktury: pytanie - odpowiedź oraz wymiany ról nadawczo-odbiorczych cechuje się dążeniem do minimalizowania dystansu między rozmówcami, z reguły małym stopniem oficjalności, emocjonalnością, a także mową naturalną, często codzienną, potoczną (por. PISAREK, red., 2006: 190; KITA, 2012: 224; KACPERSKA, 2018: 69). Do tego typu interakcji $w$ mediach nierzadko zbliżają się medialne dialogi o charakterze oficjalnym, co widać głównie w analizach współczesnych wywiadów.

Składnikiem udanej rozmowy medialnej jest grzeczność językowa. We wszelkich wymianach werbalnych funkcjonujących $w$ mediach mamy do czynienia z komunikacją na dwóch poziomach - mikrosytuacyjnym, na którym dziennikarz rozmawia z bezpośrednim partnerem dialogu (zaproszonym do interakcji gościem), oraz makrosytuacyjnym, na którym nadawca pośrednio komunikuje się z odbiorcą masowym. Z tego względu badacze komunikacji językowej traktują rozmowę medialną często nie jako dialog sensu stricto, ale jako „manifestację trilogu”, w którym uczestniczą: dziennikarz - odbiorca bezpośredni - odbiorca pośredni (por. ŚlAWSKA, 2011: 38; LoeWE, 2013: 300).

1 Na tworzenie „atmosfery grzeczności” mają wpływ nie tylko środki językowe, ale i pozajęzykowe, takie jak gest, mimika, proksemika, intonacja czy tempo mówienia, które świadczą o grzeczności niewerbalnej (por. np. MARCJANIK, 2006: 241-242; MARCJANIK, 2007: 13-19). Badania medialnych rozmów ze sportowcami ograniczono jednak do grzeczności werbalnej. 
Modzie na rozmowę $w$ mediach ulegają różne dziedziny dziennikarstwa, między innymi dziennikarstwo sportowe. Obecnie wykorzystuje się rozmaite formy oparte na wymianie werbalnej, aby w sposób atrakcyjny przedstawić kibicom sportowych idoli. Odbiorców interesuje nie tylko kariera sportowców, ale również ich osobowość, opinie dotyczące aktualnych wydarzeń czy fakty z życia prywatnego. To, w jakim stopniu zaproszony do rozmowy sportowiec zaufa dziennikarzowi, czy chętnie odpowie na jego pytania, czy otworzy się przed nim $w$ takim stopniu, by opowiedzieć o swoich poglądach i przemyśleniach, w dużej mierze zależy od tego, czy interlokutorzy realizują strategie grzecznościowe.

\section{Przedmiot, cel i metoda badań}

Aby sprawdzić, $w$ jaki sposób grzeczność językowa ujawnia się w dziennikarstwie sportowym, analizie poddano medialne rozmowy ze sportowcami. Przedmiotem badań są interakcje z reprezentantami jednej dyscypliny sportowej - siatkówki. Zostały one upublicznione na przestrzeni trzech lat ( $w$ czasie od października 2016 roku do października 2019 roku) $w$ formie audialnej oraz audiowizualnej. Pod uwagę wzięto losowo wybrane:

a) rozmowy radiowe prowadzone $z$ siatkarzami $w$ ramach audycji „Przy niedzieli o sporcie” na antenie Radia TOK FM, audycji „Warto rozbawiać” na antenie Radia Zet i programu audialnego „Kierunek Tokio” na antenie internetowego Radia Weszło FM²;

b) mikrowywiady pomeczowe przeprowadzane z siatkarzami przez dziennikarzy stacji telewizyjnej Polsat Sport i upubliczniane za pośrednictwem portalu PolsatSport.pl;

c) wywiady przeprowadzane $z$ siatkarzami $w$ ramach internetowych serii rozmów ze sportowcami („Kadziu Projekt” na portalu PolsatSport.pl i „Sam na sam” na youtubowym kanale portalu Sport.pl) oraz na wideoblogu „Prawda Siatki”.

Materiał badawczy to łącznie ponad 315 minut nagrań. Wymagały one transkrypcji, aby na dalszym etapie badań rozmowy można było je poddać analizie porównawczej. Ce-

${ }^{2}$ Wybrane do analizy rozmowy radiowe zostały upublicznione za pośrednictwem trzech różnych stacji, które warto scharakteryzować. Radio TOK FM to komercyjny nadawca ponadregionalny o charakterze informacyjno-publicystycznym, nastawiony na mówienie do i w obecności słuchacza. Potwierdza to również wizytówka zamieszczona na oficjalnej stronie internetowej rozgłośni: „Radio TOK FM - Pierwsze Radio Informacyjne jest opiniotwórczym radiem »mówionym«, $w$ którym słowo stanowi około 90\% programu antenowego" [https://audycje.tokfm.pl/radio-tokfm-informacje\#TRNauSST, dostęp: 5.07.21]. Rozmowy z przedstawicielami sportu, które przeprowadzane są w ramach audycji „Przy niedzieli o sporcie”, zawierają wiele elementów typowych dla polszczyzny oficjalnej, a nawet latynizmy i wyrazy przestarzałe. Z kolei Radio Zet to komercyjna rozgłośnia radiowa o zasięgu ogólnopolskim; swój format określa jako AC (Adult Contemporary), co uwidacznia się w przekazywaniu treści przeznaczonych dla osób dorosłych oraz ukierunkowaniu na muzykę i rozrywkę. Skupienie się na ludyczności zauważalne jest w audycji „Warto rozbawiać”, w której prowadzący Szymon Majewski w sposób lekki, przystępny oraz zabawny rozmawia z zaproszonymi do studia gośćmi. Dziennikarz dąży do minimalizowania dystansu komunikacyjnego zarówno na poziomie makro, jak i mikro, czego przejawem jest między innymi wysoki poziom potoczności oraz bezpośredniości. Natomiast Radio Weszło FM to internetowe radio specjalistyczne o tematyce sportowej oparte na przekazie werbalnym. W rozmowach prowadzonych w audycji „Kierunek Tokio” interlokutorzy posługują się mową swobodną, naturalną, w której występuje głównie słownictwo potoczne. 
lem badawczym jest bowiem przedstawienie różnic $w$ realizacji strategii grzecznościowych między trzema wybranymi typami medialnych rozmów ze sportowcami: wywiadem radiowym (dialogiem w postaci klasycznej), mikrowywiadem pomeczowym (rozmową typową dla dziennikarstwa sportowego) a wywiadem internetowym (najnowszą formą medialnej komunikacji z zawodnikami).

\section{Odmiany medialnych rozmów ze sportowcami - charakterystyka ${ }^{3}$}

Wywiad radiowy to zdecydowanie dłuższa od pozostałych forma interakcji między przedstawicielem mediów a sportowcem. Za sprawą przekazu audialnego budowana jest specyficzna atmosfera kameralności i intymności, skłaniająca bohatera wywiadu do otwarcia się przed dziennikarzem (zwłaszcza w przypadku wywiadu zwierzeniowego). Tę specyfikę przekazu radiowego widać także na poziomie makrosytuacyjnym - odbiór ma charakter indywidualny, osobisty, co ujawnia się $w$ formach adresatywnych. Siatkarze są zapraszani do rozmowy z dziennikarzami na antenie radiowej najczęściej w związku z odniesieniem znaczącego sukcesu sportowego (np. zdobycie tytułu mistrza świata) czy ogłoszeniem zakończenia kariery zawodniczej przez sportowca.

Charakterystycznym dla dziennikarstwa sportowego typem krótkiej interakcji między dziennikarzem a zawodnikiem jest z kolei mikrowywiad pomeczowy. To forma dialogowa nastawiona przede wszystkim na zwięzłą wymianę opinii na temat zakończonego właśnie spotkania sportowego. Oprócz tego cechuje się wysokim poziomem spontaniczności oraz dużym ładunkiem emocjonalnym zwłaszcza u odpowiadającego (sportowca), co zazwyczaj jest interesujące dla odbiorcy medialnego. Do mikrowywiadów pomeczowych najczęściej zaprasza się siatkarzy, którzy wyróżniali się bardzo dobrą postawą na boisku, reprezentujących zarówno drużynę wygraną, jak i przegraną.

Nieograniczone możliwości komunikacji ze sportowcami daje przestrzeń internetowa, stąd trzecią odmianą rozmów medialnych, którą wzięto pod uwagę, jest wywiad internetowy. Oprócz serwisów społecznościowych, za których pośrednictwem można organizować na przykład rozmowy typu live chat, upubliczniane są także autorskie cykle rozmów ze sportowcami $w$ formie audiowizualnej. W roli gospodarza i moderatora rozmowy może występować dziennikarz (czego przykładem jest cykl „Sam na sam” Pawła Wilkowicza, redaktora naczelnego portalu Sport.pl) lub były sportowiec (jak w przypadku autorskiego programu „Kadziu Project” Łukasza Kadziewicza - byłego siatkarza i byłego komentatora stacji telewizyjnej Polsat Sport). Rozmowy medialne z zawodnikami pojawiają się też $w$ ramach wideoblogowej działalności dziennikarzy sportowych, między innymi w wideoblogu „Prawda Siatki” Jerzego Mielewskiego i Marcina Lepy.

${ }^{3}$ Ze względu na ograniczone możliwości wydawnicze w artykule zamieszczono krótkie charakterystyki analizowanych rozmów medialnych ze sportowcami. Bardziej szczegółowy opis omawianych form interakcji można odnaleźć $\mathrm{w}$ monografii Współczesne oblicza medialnych rozmów o sporcie (KACPERSKA, 2021). 


\section{Zwroty grzecznościowe $w$ medialnych rozmowach ze sportowcami}

$W$ analizie relacji partnerskich $w$ medialnych rozmowach $z$ przedstawicielami sportu na poziomach mikro- i makrosytuacyjnym pod uwagę wzięto używane przez uczestników dialogu zwroty grzecznościowe. MARCJANIK definiuje je jako te wypowiedzi, które mają cel komunikacyjny związany z dyrektywą obyczajową „nie wypada nie...” (por. 2017: 5). W badanych interakcjach występują zwroty grzecznościowe należące do dwóch podstawowych grup, które wyróżnił Kazimierz Ożóg (1990). Są to:

a) pierwszorzędne zwroty grzecznościowe określane jako niezbędne do prawidłowego przebiegu kontaktu językowego, czyli formy adresatywne, powitania, sposoby przedstawiania siebie i rozmówcy, prośby, przeprosiny, podziękowania, pożegnania;

b) drugorzędne zwroty grzecznościowe, których podstawowym zadaniem jest wyrażanie więzi społecznej, na przykład formy wyrażające aprobatę dla rozmówcy, pochwały, gratulacje, zaproszenia, pozdrowienia, życzenia.

Z tą typologią ściśle wiąże się podział zaproponowany przez Małgorzatę KıтE (por. 2016: 198-200). Językoznawczyni uwzględnia w nim stopień powszechności zwrotów realizujących funkcję grzecznościową w społeczeństwie oraz zwraca uwagę na dwa typy grzeczności:

a) grzeczność elementarna, stosowana „na co dzień” i obowiązująca wszystkich członków społeczeństwa; należą do niej te zwroty grzecznościowe, które Ożóg nazywa pierwszorzędnymi;

b) grzeczność wyszukana, wyrafinowana, elitarna tworząca atmosferę uprzejmości i kurtuazji - jej przejawy są nadbudowane nad grzecznością elementarną; wiąże się z używaniem takich środków językowych, które wyrażają „dbałość o dobre samopoczucie uczestników aktu komunikacyjnego. To nie tylko »nie szkodzić«, lecz - przede wszystkim - pomagać, sprawiać $w$ naturalny i niewymuszony sposób bezinteresownie przyjemność - drugiemu, ale i sobie" (KıTA, 2016: 199).

Innym ważnym podziałem jest ten zaproponowany przez MARCjANIK (2017), która oprócz autonomicznych oraz nieautonomicznych aktów grzecznościowych wyodrębnia grzecznościową obudowę aktów, na którą składają się elementy wypowiedzi niemające mocy predykatywnej i pełniące funkcję etykietalną. Na podstawie typologii Ożoga, Kity i Marcjanik przejawy grzeczności językowej, które występują w poszczególnych typach medialnych rozmów ze sportowcami (wywiadzie radiowym, mikrowywiadzie pomeczowym oraz wywiadzie internetowym), zostały podzielone na trzy zasadnicze grupy: 1) zwroty związane z grzecznością elementarną (por. tabela 1), 2) zwroty związane z grzecznością elitarną, 3) grzecznościową obudowę wypowiedzi (por. tabela 2). W dalszej części artykułu każda z nich zostanie szczegółowo omówiona.

\subsection{Grzeczność elementarna}

Do pierwszej grupy zwrotów świadczących o grzeczności językowej w medialnych dialogach między dziennikarzami a sportowcami należą formy zwracania się do odbiorcy, czyli tzw. formy adresatywne. Są to takie zuroty grzecznościowe, które od początku rozmowy budują relację z partnerem dialogu, decydują o poziomie dystansu komunikacyjnego i wyrażają stosunek emocjonalny wobec rozmówcy. W analizowanych rozmowach na poziomie 
makrosytuacyjnym brakuje konsekwencji w stosowaniu bezpośrednich zurotów do odbiorcy masowego. W wywiadach radiowych oraz internetowych przedstawiciele mediów stosują zarówno oficjalną formę państwo (na przykład Paweł Zagumny jest moim i państwa gościem (5.03.2017) - WR ${ }^{4}$ ), jak i potoczne, bezpośrednie formy w 2. osobie liczby mnogiej, typowe dla relacji na ty, które budują wspólnotowość (typu Poznajecie tego dżentelmena? (31.08.2018) - WI). Zdarza się, że moderator wymiany używa obu form w czasie tego samego wywiadu, por. Ja już nie chcę, proszę państwa, przesadnie chwalić Trójmiasta; Ja stoję, Piotrek siedzi i jestem jego wzrostu, bo tego nie widzicie, ale magia radia, więc wam to opowiadamy (4.12.2018) - WR. W przeanalizowanych mikrowywiadach pomeczowych nie wystąpiły bezpośrednie zwroty do odbiorcy masowego, co prawdopodobnie wiąże się ze zwięzłością tej wypowiedzi.

Na poziomie mikrosytuacyjnym z reguły występują formy adresatywne typowe dla relacji na ty, co ujawnia się w wypowiedziach zarówno dziennikarzy, jak i sportowców, o czym świadczą stosowane przez nich zaimki osobowe oraz formy czasowników. We wszystkich odmianach rozmów medialnych dziennikarz zwraca się do swojego rozmówcy po imieniu, najczęściej z użyciem form równych mianownikowi liczby pojedynczej (a nie wołacza liczby pojedynczej), co jest charakterystyczne dla polszczyzny potocznej, stosuje także zdrobnienia, na przykład Kuba, masz prawo jazdy w ogóle? (26.08.2018) - WI. W wywiadach radiowych zdarza się, że przedstawiciel mediów, zwracając się do partnerów rozmowy, używa grzecznego i dość oficjalnego zwrotu panowie (mimo tego, że pozostaje z nimi w relacji na ty), na przykład Panowie, uwaga, pytanie do każdego z was po jednym abstrakcyjnym (8.10.2018) - WR. Jeśli chodzi o interwencje gościa rozmowy, w nich sportowcy nie używają imion, ale zwracają się do dziennikarzy formami czasownika w 2. osobie liczby pojedynczej (na przykład Staram się razem z żoną odwiedzać tą halę, bo, tak ja ty wcześniej powiedziałeś, jest to jedna z najpiękniejszych hal w Polsce (4.12.2018) - WR).

Niezbędnymi do prawidłowego przebiegu interakcji zwrotami grzecznościowymi są również sposoby przedstawiania siebie i rozmówcy oraz powitania, które stanowią elementy części inicjalnej medialnych rozmów ze sportowcami. Prowadzący wywiady radiowe i internetowe rozpoczynają interakcję od przedstawienia się odbiorcom, co ogranicza się do podania imienia oraz nazwiska. Do tego w formule inicjalnej wskazują na nazwę prowadzonej przez siebie audycji i/lub stacji radiowej (w przypadku wywiadów radiowych) albo nazwę programu, cyklu rozmów czy wideobloga, w którego ramach upubliczniane są dialogi ze sportowcami (w przypadku wywiadów internetowych). W mikrowywiadach pomeczowych dziennikarz rezygnuje z przedstawiania samego siebie, co najprawdopodobniej jest spowodowane lapidarnością i zwięzłością tej formy interakcji ze sportowcem.

We wszystkich analizowanych odmianach medialnej rozmowy z siatkarzami zdecydowanie bardziej rozbudowane jest przedstawienie bohatera wywiadu. Przedstawiciel mediów, oprócz podania imienia i nazwiska sportowca, wymienia jego osiągnięcia zawodowe, co niekiedy połączone jest z pochwałą dokonań, na przykład Dziś moim i państwa gościem jest Paweł Zagumny, siatkarski mistrz świata z 2014 roku, wicemistrz świata z 2006 roku, mistrz

${ }^{4}$ Fragmenty medialnych rozmów ze sportowcami zapisywane są $w$ artykule kursywą. Każdy cytat jest opatrzony datą upublicznienia dialogu i informacją, jaki to typ interakcji (WR - wywiad radiowy, MP - mikrowywiad pomeczowy, WI - wywiad internetowy). 
świata juniorów, właściwie $w$ swojej palecie reprezentacyjnej kariery zdobył już absolutnie wszystko (5.03.2017) - WR. W zwrotach grzecznościowych związanych z przedstawianiem siebie i swojego rozmówcy $w$ odmianach medialnej rozmowy ze sportowcem eksponuje się zatem bohatera dialogu - prezentacja jego sylwetki jest bardziej rozbudowana $w$ porównaniu z przedstawianiem siebie przez dziennikarza (która ogranicza się do lakonicznej formy autoprezentacji) i skoncentrowana na sportowych zasługach siatkarza. W ten sposób ujawnia się typowa dla polskiej kultury reguła grzeczności językowej, którą MARcjanik nazywa regułą bycia podwładnym (por. 2006: 286; 2017: 6).

W wywiadach radiowych i internetowych na poziomie makro występuje jeden z najbardziej rozpowszechnionych zwrotów służących powitaniu - witam - który wzmacniany jest przysłówkami wartościującymi pozytywnie, na przykład witam was bardzo gorąco (4.12.2018) - WR, słuchajcie, witamy serdecznie, "Prawda Siatki” (26.08.2018) - WI. Do tego w wypowiedziach gospodarzy audycji pojawia się zwrot do słuchaczy kłaniam się państwu (5.03.2017), który jest uznawany przez MARCJANIK za typową dla kontaktów pośrednich i chętnie stosowaną przez prezenterów radia formę grzecznościową (por. 2017: 29). Na poziomie mikro stosowane są uniwersalne grzecznościowe formy powitalne typu dzień dobry, witam, cześć. W powitaniach występujących w wywiadach radiowych oraz internetowych realizowana jest także reguła symetryczności zachowań grzecznościowych - najpierw dziennikarz wita swojego gościa, po czym bohater interakcji odpowiada podobnym zwrotem. Form powitalnych nie zauważa się jedynie $w$ mikrowywiadach pomeczowych, co, jak można przypuszczać, spowodowane jest tym, że powitanie rozmówców odbyło się przed włączeniem kamery ( $w$ tzw. kulisach) i nie zostało zarejestrowane ze względu na fakt, iż ten typ wymiany jest krótki.

Przejawem grzeczności elementarnej są także prośby, które wystąpiły $w$ analizowanych wymianach radiowych i pomeczowych. W rozmowach prowadzonych za pośrednictwem radia są one kierowane przez prowadzącego, który używa grzecznych form prośby o informację typu chciałbym wrócić..., na przykład Jeszcze chciałbym wrócić do siatkówki na koniec naszej rozmowy (5.03.2017) - WR oraz chciałem zapytać..., na przykład Chciałem zapytać też o drugiego z trenerów, czyli o Andreę Anastasiego (4.12.2018) - WR. Dziennikarz stosuje niekiedy zwrot proszę, który wtrącony do wypowiedzi mającej formę polecenia, lecz pełniącej funkcję prośby, jest próbą osłabienia polecenia wyrażonego czasownikiem, na przykład: Powiedz, proszę, co było twoim [...] największym atutem? (5.03.2017) - WR. W mikrowywiadach pomeczowych prośby występują $w$ wypowiedziach sportowców; są kierowane do kibiców (poziom makrosytuacyjny) i połączone z zaproszeniem typu Kibice naprawdę sa fantastyczni. Miejmy nadzieję, że tak samo będzie $w$ kolejnych fazach turnieju, nie tylko tutaj. Serdecznie wszystkich zapraszamy i prosimy o pomoc (16.09.2019) - MP.

W sytuacjach, kiedy podczas medialnej wymiany werbalnej ze sportowcem interlokutor ma wrażenie, iż jego zachowanie mogłoby zostać uznane przez partnera dialogu za niegrzeczne, stosowane są zuroty o funkcji przeproszenia. Dzieje się tak na przykład w okolicznościach, gdy dziennikarz często (być może zbyt często) odwołuje się do innej dyscypliny sportowej niż siatkówka, na przykład Ja przepraszam za te analogie, ale ta piłka [nożna - B.K.] jest mi gdzieś bliska (5.03.2017) - WR, lub gdy w wypowiedzi sportowca pojawia się mimowolne zachowanie parajęzykowe typu odchrząknięcie - WR. Zagrożeniem 
komunikacji opartej na dialogu jest przerywanie rozmówcy. Takie zachowanie stanowi przejaw braku grzeczności językowej. Analiza zgromadzonego materiału badawczego pokazuje, że rozmówcy bardzo rzadko wchodzą sobie $w$ słowo i przerywają partnerowi, nie pozwalając mu skończyć wypowiedzi. Wymiany werbalne między dziennikarzami a sportowcami w zdecydowanej większości są uprzejme, swobodne, naturalne. Nawet jeśli zdarzy się sytuacja, w której interlokutor przerwie wypowiedź swojego partnera, to, kierując się zasadą grzeczności, natychmiast za to przeprasza, na przykład Ale wiesz, jaki jest powód? Przepraszam, że wejdę ci w słowo, znowu do piłki nożnej [...] (5.03.2017) - WR.

O grzeczności elementarnej świadczą także składowe części finalnej rozmowy medialnej ze sportowcem, czyli podziękowania oraz pożegnania. W analizowanych dialogach grzecznościowe zwroty o funkcji podziękowania występują we wszystkich odmianach wywiadu. Są inicjowane przede wszystkim przez dziennikarzy i stanowią sygnał zakończenia wymiany, a sportowcy, zgodnie z grzecznościową regułą symetryczności, odpowiadają na nie podobnym zwrotem. Tego typu formuły grzecznościowe mają postać najbardziej popularnej $w$ kulturze polskiej formy podziękowań - dziękuję, która zazwyczaj występuje z przysłówkiem, na przykład Dziękuję pięknie. Fabian Drzyzga, MVP dzisiejszego spotkania (15.10.2016) - MP, Bartek, bardzo dziękuję za wywiad (8.10.2018) - WR. Zdarza się, że $w$ interakcjach występuje skrócona forma dzięki z przymiotnikiem wielkie, która w kulturze polskiej powinna być stosowana tylko $w$ relacjach na ty (por. MARCJANıK, 2017: 204). Do tego grzecznościowe zwroty wskazujące na podziękowanie są używane przez sportowców na poziomie makrosytuacyjnym, kiedy to w imieniu całej drużyny zwracają się do odbiorców/kibiców, którym dziękują za doping: Gramy kilkaset kilometrów od domu, a czujemy się tak, jakbyśmy grali $w$ Gdańsku albo innym polskim mieście, więc dziękujemy (16.09.2019) - MP. Jeśli zaś chodzi o pożegnania, to zauważa się je tylko $w$ analizowanych wywiadach radiowych, $w$ których moderator rozmowy zwraca się do słuchaczy formą do usłyszenia.

Tabela 1

Przejawy językowej grzeczności elementarnej

w medialnych rozmowach ze sportowcami - analiza porównawcza

\begin{tabular}{|c|c|c|c|}
\hline \multirow{2}{*}{$\begin{array}{l}\text { Grzeczność } \\
\text { elementarna }\end{array}$} & \multicolumn{3}{|c|}{ Typy wywiadu } \\
\hline & wywiad radiowy & mikrowywiad pomeczowy & wywiad internetowy \\
\hline 1 & 2 & 3 & 4 \\
\hline $\begin{array}{l}\text { Formy } \\
\text { adresatywne }\end{array}$ & $\begin{array}{l}\text { - poziom makro: relacja } \\
\text { nieoficjalna (na ty) / } \\
\text { relacja oficjalna (na } \\
\text { państwo) } \\
\text { - poziom mikro: relacja } \\
\text { nieoficjalna (na ty) }\end{array}$ & $\begin{array}{l}\text { - poziom makro: brak } \\
\text { - poziom mikro: relacja } \\
\text { nieoficjalna (na ty) / } \\
\text { relacja oficjalna (na } \\
\text { pan) tylko sportowiec } \rightarrow \\
\text { dziennikarz }\end{array}$ & $\begin{array}{l}\text { - poziom makro: relacja } \\
\text { nieoficjalna (na ty) / } \\
\text { relacja oficjalna } \\
\text { (na państwo) } \\
\text { - poziom mikro: relacja } \\
\text { nieoficjalna (na ty) }\end{array}$ \\
\hline Powitania & $\begin{array}{l}\text { - poziom makro: kłaniam } \\
\text { się państwu, witam } \\
\text { (serdecznie, bardzo } \\
\text { goraco) } \\
\text { - poziom mikro: dzień } \\
\text { dobry, witam [reguła } \\
\text { symetryczności] }\end{array}$ & - & $\begin{array}{l}\text { - poziom makro: witam } \\
\text { (serdecznie) } \\
\text { - poziom mikro: cześć, } \\
\text { witam [reguła syme- } \\
\text { tryczności] }\end{array}$ \\
\hline
\end{tabular}


cd. tab. 1

\begin{tabular}{|c|c|c|c|}
\hline 1 & 2 & 3 & 4 \\
\hline $\begin{array}{l}\text { Przedstawianie } \\
\text { siebie i kogoś }\end{array}$ & $\begin{array}{l}\text { - przedstawianie siebie: } \\
\text { imię, nazwisko } \\
\text { - podanie nazwy audycji, } \\
\text { - przedstawianie sportow- } \\
\text { ca: imię, nazwisko, naj- } \\
\text { ważniejsze osiągnięcia } \\
\text { sportowe [reguła bycia } \\
\text { podwładnym] }\end{array}$ & $\begin{array}{l}\text { - przedstawianie siebie: } \\
\text { brak } \\
\text { - przedstawianie spor- } \\
\text { towca: imię, nazwisko, } \\
\text { klub, pozycja na boisku } \\
\text { [reguła bycia podwład- } \\
\text { nym] }\end{array}$ & $\begin{array}{l}\text { - przedstawianie siebie: } \\
\text { imię, nazwisko } \\
\text { - podanie nazwy pro- } \\
\text { gramu } \\
\text { - przedstawianie spor- } \\
\text { towca: imię, nazwisko, } \\
\text { pozycja na boisku, naj- } \\
\text { ważniejsze osiągnięcia } \\
\text { sportowe [reguła bycia } \\
\text { podwładnym] }\end{array}$ \\
\hline Prośby & $\begin{array}{l}\text { poziom mikro: pytania } \\
\text { (dziennikarz } \rightarrow \text { sporto- } \\
\text { wiec) }\end{array}$ & $\begin{array}{l}\text { poziom makro: sportowiec } \\
\rightarrow \text { widzowie }\end{array}$ & - \\
\hline Przeprosiny & $\begin{array}{l}\text { wypowiedzi dziennikarza } \\
\text { i sportowca }\end{array}$ & - & $\begin{array}{l}\text { wypowiedzi dziennikarza } \\
\text { i sportowca }\end{array}$ \\
\hline Podziękowania & $\begin{array}{l}\text { na poziomie mikro: dzię- } \\
\text { kuję (bardzo, serdecznie), } \\
\text { dzięki (wielkie) [reguła } \\
\text { symetryczności] }\end{array}$ & $\begin{array}{l}\text { - poziom makro: sporto- } \\
\text { wiec } \rightarrow \text { widzowie } \\
\text { - poziom mikro: dziękuję } \\
\text { (pięknie, bardzo, ser- } \\
\text { decznie), dzięki (wielkie) } \\
\text { [reguła symetryczności] }\end{array}$ & $\begin{array}{l}\text { na poziomie mikro: } \\
\text { dziękuję, dzięki (bardzo, } \\
\text { serdeczne) [reguła syme- } \\
\text { tryczności] }\end{array}$ \\
\hline Pożegnania & $\begin{array}{l}\text { poziom makro: dzien- } \\
\text { nikarz } \rightarrow \text { widzowie } \\
\text { (do usłyszenia) }\end{array}$ & - & - \\
\hline
\end{tabular}

Źródło: Opracowanie własne.

\subsection{Grzeczność elitarna}

Przejawem dbałości o dobre samopoczucie partnera dialogu jest stosowanie form aprobaty dla działań rozmówcy (wypowiadanych sądów lub potwierdzenia słów interlokutora), które zauważa się we wszystkich analizowanych odmianach rozmów medialnych, w interwencjach zarówno dziennikarzy, jak i sportowców. Wśród nich wymienić można przede wszystkim:

a) tak (tak, tak) - formę potakiwania rozmówcy, która służy podtrzymaniu kontaktu werbalnego;

b) zdecydowanie tak, dokładnie tak, na pewno, no zdecydowanie, no oczywiście - zwroty grzecznościowe służące nie tylko potwierdzeniu tego, o czym mówi rozmówca, ale także wyrażeniu zrozumienia dla jego działań;

c) zgadza się - formę aprobaty dla tego, co mówi rozmówca.

O grzeczności elitarnej $w$ medialnych rozmowach ze sportowcami świadczą także pochwały występujące we wszystkich trzech typach dialogu na poziomie mikrosytuacyjnym w wypowiedziach dziennikarza i kierowane do sportowca. Zwroty grzecznościowe służące wyrażeniu pochwały $w$ analizowanych wymianach najczęściej dotyczą sportowych umiejętności lub osiągnięć rozmówcy. Niekiedy są elementem przedstawienia rozmówcy, na przykład Absolutny bohater dzisiejszego spotkania, MVP łatwy do wskazania, Mariusz Wlazły (7.01.2017) - MP, czasem stanowią wprowadzenie do zadania pytania, przykłado- 
wo Idealnie prowadzisz swoją karierę: Warszawa, Radom i skok na głęboka wodę. Długo zastanawiałeś się nad tym transferem, rozważałeś plusy i minusy? (1.10.2016) - WI.

W wypowiedziach sportowca realizowane są reguły polskiej grzeczności wskazane przez MARCJANIK: reguła symetryczności (sportowiec reaguje na pochwałę), a także reguła bycia podwładnym, według której odpowiednią reakcją na wszelkie formy dodatniego wartościowania, w tym na pochwały, są duża wstrzemięźliwość, skromność oraz umniejszanie własnych dokonań - $w$ tym przypadku sportowych. Jak argumentuje MARCjANIK, „wynika to $z$ tradycji - z wpajanych nam i naszym przodkom $w$ procesie wychowania zasad skromności, pokory, niewywyższania się" (2017: 116):

D: A ty znasz się z Tomkiem tapińskim? [...] moim zdaniem jesteście mentalnie braćmi bliźniakami.

S: Pamiętam, że był dobrym obrońca, tylko tyle mogę powiedzieć o Tomku Łapińskim.

D: A ty za to znakomitym rozgrywającym, najlepszym na świecie.

S: Był moment, że grałem dobrze, ale czy byłem najlepszy na świecie to chyba nie mi oceniać. Mi się wydaje, że nigdy nie byłem najlepszy.

$5.03 .2017-W R$

W medialnych rozmowach ze sportowcami realizowana jest także strategia solidarności z partnerem, polegająca na współodczuwaniu i współdziałaniu z rozmówcą. Jej przejawami są między innymi gratulacje, które nie wystąpiły tylko w analizowanych wywiadach internetowych. W pozostałych rozmowach tego typu zwroty grzecznościowe są stosowane przez dziennikarza i odnoszą się albo do międzynarodowego sukcesu całej drużyny, jakim jest zdobycie złotego medalu na mistrzostwach świata, na przykład Panowie, wielkie gratulacje ode mnie i od wszystkich Polaków (8.10.2018) - WR, albo do bardzo dobrej postawy rozmówcy $w$ danym meczu, co widać zwłaszcza $w$ mikrowywiadach pomeczowych:

D: Gdyby to ode mnie zależało, Dawid, ty byś dostał dzisiaj statuetke dla najlepszego gracza meczu. Może tam w liczbach rzeczywiście Sam [Deroo, siatkarz B.K.] wypadł troszeczke lepiej, ale wszystkie najważniejsze piłki tego spotkania ty dostałeś i, co my zauważyliśmy z Łukaszem [Kadziewiczem, współkomentującym mecz - B.K.], wszystkie skończyłeś. Gratulacje!

$\mathrm{S}:$ A no to cieszę się, cieszę się bardzo [...].

16.10.2016 - MP

W mikrowywiadach pomeczowych gratulacje zauważa się także $w$ interwencjach sportowca, który grzecznościowe zwroty kieruje do drużyny przeciwnej - uwidacznia się zatem kolejna cecha grzeczności językowej, czyli eleganckie, uprzejme mówienie o kimś (tutaj: o przeciwniku), na przykład Oczywiście trzeba podkreślić, że ZAKSA bardzo dobrze grała, oni graja bardzo równo cały sezon i generalnie ciężko się do nich dobrać, i gratulacje też za te dwa pierwsze sety, bo postawili nam ciężkie warunki [...] (7.01.2017) - MP.

Gratulacje to nie jedyne zwroty grzecznościowe potwierdzające realizację reguły solidarności z rozmówcą. W rozmowach medialnych na antenie radiowej pojawiają się także inne 
wyrazy współodczuwania świadczące o empatii mówiącego, będące reakcją na trudne wydarzenia (związane np. z urazami i kontuzjami), którymi siatkarz dzieli się podczas dialogu:

S: Dostałem też kartkę do podpisania z możliwymi powikłaniami po narkozie, ale, to wiadomo, każdy...

D: Znam ten ból, tak...

S: No właśnie.

4.12.2018-WR

O grzeczności elitarnej $w$ rozmowach ze sportowcami świadczą również zaproszenia oraz pozdrowienia, które są kierowane do odbiorców (poziom makrosytuacyjny). W mikrowywiadach pomeczowych zaproszenia występują $w$ wypowiedziach sportowców, którzy zachęcają kibiców do przyjścia na mecze. W wywiadach internetowych tego typu zwroty pojawiają się $w$ interwencjach dziennikarza $w$ części wprowadzającej do rozmowy, $w$ której odbiorcy są zapraszani do obejrzenia wywiadu, na przykład Zapraszam na najnowszy odcinek "Sam na sam” (14.12.2018) - WI. Pozdrowienia z kolei występują w wypowiedziach sportowca i są kierowane do ogółu, na przykład Bardzo miło wracać tutaj, do Gdańska, do mojej ulubionej hali, do mojego ulubionego miasta, w którym już mieszkam. Pozdrawiam wszystkich serdecznie (10.08.2019) - MP, lub do wybranej osoby, na przykład Pozdrawiamy cię, Krzysiu, serdecznie bardzo (31.08.2018) - WI. Zaproszeń i pozdrowień nie odnotowano jedynie w wywiadach radiowych.

Do przejawów grzeczności wysublimowanej należą również życzenia. W analizowanych rozmowach ze sportowcem takie zwroty grzecznościowe pojawiają się w części kończącej wywiad - albo w wypowiedziach dziennikarza, na przykład [...] zdrowia, oby jak najmniej $w$ gabinecie lekarskim, a jak najwięcej na boisku (3.10.2016) - WI, albo w interwencjach sportowca, który życzenia kieruje do innego siatkarza, na przykład Życzę mu z całego serca, żeby był najlepszy na świecie (4.12.2018) - WR. Tego typu zwroty grzecznościowe stanowią także uprzejmą reakcję dziennikarza na to, o czym mówi sportowiec:

S: Myślę, że jak złapiemy jeszcze o wiele więcej tego takiego pozytywnego feelingu ze sobq i zgrania, to będziemy niebezpieczna drużyną.

D: Tego ci życzę.

26.08.2018-WI

\subsection{Grzecznościowa obudowa wypowiedzi}

Na grzecznościową obudowę komunikatów składają się te elementy wypowiedzi, które „nie wskazują na jej treść (czy cel komunikacyjny), lecz wyrażają empatyczny stosunek do odbiorcy" (MARCJANIK, 2017: 190). Tego typu wyrażenia występują we wszystkich typach medialnych rozmów ze sportowcami. Wśród nich można wskazać między innymi z całym szacunkiem do/dla..., czyli zwrot mający na celu osłabienie krytyki pod czyimś adresem ( $w$ przypadku mikrowywiadów pomeczowych - skierowanej do drużyny przeciwnej), na przykład Z całym szacunkiem dla Czechów, ale jesteśmy od nich lepszym zespołem i chcieliśmy to udowodnić na boisku (16.09.2019) - MP, miałem przyjemność, czyli dosłowne i grzeczne wyrażenie tego, że wydarzenie, które odbyło się w przeszłości i jest 
związane z rozmówcą, dostarczyło mówiącemu pozytywnych wrażeń, na przykład Mia†em przyjemność komentowania waszych meczów u nas $w$ radiu z Krzyśkiem Ignaczakiem (4.12.2018) - WR, czy jeżeli mogę zasugerować, czyli grzeczna forma wprowadzenia jakiegoś pomysłu, która jednocześnie jest próbą osłabienia polecenia wyrażonego czasownikiem, na przykład To i na igrzyskach razem zamieszkajcie, jeżeli mogę coś zasugerować (4.12.2018) - WR.

Tabela 2

Przejawy językowej grzeczności elitarnej i grzecznościowa obudowa wypowiedzi $w$ medialnych rozmowach ze sportowcami - analiza porównawcza

\begin{tabular}{|c|c|c|c|}
\hline \multirow{2}{*}{$\begin{array}{c}\text { Grzeczność } \\
\text { elitarna }\end{array}$} & \multicolumn{3}{|c|}{ Typy wywiadu } \\
\hline & wywiad radiowy & mikrowywiad pomeczowy & wywiad internetowy \\
\hline $\begin{array}{l}\text { Formy aprobaty } \\
\text { dla rozmówcy }\end{array}$ & $\begin{array}{l}\text { wypowiedzi dziennikarza } \\
\text { i sportowca: tak, no tak, } \\
\text { zgadza się, no zgadza } \\
\text { się, acha, no dokładnie, } \\
\text { no na pewno }\end{array}$ & $\begin{array}{l}\text { wypowiedzi dziennikarza } \\
\text { i sportowca: tak (tak, } \\
\text { tak), dokładnie tak, zde- } \\
\text { cydowanie tak, na pew- } \\
\text { no, no zdecydowanie, } \\
\text { no oczywiście, zgadza się }\end{array}$ & $\begin{array}{l}\text { wypowiedzi dziennikarza } \\
\text { i sportowca: tak, jasne, } \\
\text { dobrze, że..., zgadza się }\end{array}$ \\
\hline Pochwały & $\begin{array}{l}\text { poziom mikro: dzienni- } \\
\text { karz } \rightarrow \text { sportowiec [regu- } \\
\text { ły symetryczności i bycia } \\
\text { podwładnym] }\end{array}$ & $\begin{array}{l}\text { poziom mikro: dzienni- } \\
\text { karz } \rightarrow \text { sportowiec/dru- } \\
\text { żyna }\end{array}$ & $\begin{array}{l}\text { poziom mikro: dzienni- } \\
\text { karz } \rightarrow \text { sportowiec [regu- } \\
\text { ły symetryczności i bycia } \\
\text { podwładnym] }\end{array}$ \\
\hline Gratulacje & wypowiedzi dziennikarza & $\begin{array}{l}\text { wypowiedzi dziennikarza } \\
\text { i sportowca }\end{array}$ & - \\
\hline Zaproszenia & - & $\begin{array}{l}\text { poziom makro: sporto- } \\
\text { wiec } \rightarrow \text { widzowie }\end{array}$ & $\begin{array}{l}\text { poziom makro: dzienni- } \\
\text { karz } \rightarrow \text { widzowie }\end{array}$ \\
\hline Pozdrowienia & - & $\begin{array}{l}\text { poziom makro: sporto- } \\
\text { wiec } \rightarrow \text { widzowie }\end{array}$ & $\begin{array}{l}\text { poziom makro: sporto- } \\
\text { wiec } \rightarrow \text { widzowie }\end{array}$ \\
\hline Życzenia & $\begin{array}{l}\text { - poziom makro: sporto- } \\
\text { wiec } \rightarrow \text { widzowie } \\
\text { - poziom mikro: dzienni- } \\
\text { karz } \rightarrow \text { sportowiec }\end{array}$ & $\begin{array}{l}\text { poziom makro: } \\
\text { sportowiec } \rightarrow \text { widzowie }\end{array}$ & $\begin{array}{l}\text { poziom mikro: } \\
\text { dziennikarz } \rightarrow \text { sportowiec }\end{array}$ \\
\hline $\begin{array}{l}\text { Grzecznościowa } \\
\text { obudowa } \\
\text { wypowiedzi }\end{array}$ & $\begin{array}{l}\text { wypowiedzi dziennika- } \\
\text { rza i sportowca: miałem } \\
\text { przyjemność, nie miałem } \\
\text { przyjemności, jeżeli mogę } \\
\text { zasugerować... }\end{array}$ & $\begin{array}{l}\text { wypowiedzi sportowca: } \\
\text { z całym szacunkiem } \\
\text { do/dla... }\end{array}$ & $\begin{array}{l}\text { wypowiedzi dziennikarza: } \\
\text { mam nadzieję, że... }\end{array}$ \\
\hline
\end{tabular}

Źródło: Opracowanie własne.

\section{Podsumowanie}

Analiza podstawowych odmian medialnych rozmów o sporcie - wywiadów radiowych, mikrowywiadów pomeczowych oraz wywiadów internetowych - dowodzi, że dialogi między dziennikarzami a sportowcami są prowadzone w sposób uprzejmy, taktowny i grzeczny. O grzeczności elementarnej oraz elitarnej $w$ medialnych interakcjach z zawodnikami świadczy duże nagromadzenie zwrotów grzecznościowych w wypowiedziach interlokutorów. 
Więcej ich występuje $w$ interwencjach przedstawicieli mediów, co widoczne jest zułaszcza $w$ formach zwracania się do rozmówcy, ale wiąże się to z rolą dziennikarza $w$ interakcji jako prowadzący i moderujący rozmowę zadaje pytania, rozpoczyna, podtrzymuje, a także kończy wymianę werbalną. Nie oznacza to jednak, że dziennikarz to pierwszoplanowa postać $w$ rozmowie medialnej. Wręcz przeciwnie - to bohater wywiadu jest najważniejszy, a dziennikarz stanowi dla niego wsparcie, pełni rolę uważnego słuchacza, który jest ciekawy odpowiedzi oraz z zachowaniem reguł grzecznościowych reaguje na wypowiedzi swojego gościa. Ich dialog jest naturalny, swobodny i chociaż zdarzają się sytuacje przerywania komunikatu przez partnera, wówczas także stosowane są wyrażenia o funkcji grzecznościowej. Ponadto sportowiec odpowiada na przejawy grzeczności językowej, takie jak na przykład powitania, podziękowania czy pochwały, i w ten sposób realizowane są podstawowe reguły polskiej grzeczności wyodrębnione przez MARCJANIK - symetryczności zachowań grzecznościowych, bycia podwładnym oraz solidarności z partnerem.

W wywiadach radiowych, mikrowywiadach pomeczowych oraz wywiadach internetowych widoczna jest liberalizacja obowiązującej etykiety grzecznościowej $w$ mediosferze, o której językoznawcy często wspominają w swoich pracach (por. Kudra, 2008: 57; SіткошSкA, 2013: 160). W wymianach między przedstawicielami mediów a zawodnikami uwidacznia się ona głównie $w$ stosowaniu bezpośrednich form adresatywnych i zwracaniu się do siebie po imieniu, lecz wydaje się, iż obecnie jest to sposób na minimalizowanie dystansu komunikacyjnego, na poziomie zarówno mikro-, jak i makrosytuacyjnym, a nie przejaw lekceważenia odbiorcy.

Wyjątkową odmianą rozmowy okazał się mikrowywiad pomeczowy, w którym nie zauważa się niektórych zwrotów grzecznościowych typowych dla grzeczności elementarnej (form powitalnych oraz pożegnalnych, zwrotów związanych z autoprezentacją dziennikarza oraz przeprosin). Wynika to jednak ze specyfiki tej formy komunikacji - interlokutorzy mają mało czasu na rozmowę (mikrowywiad pomeczowy trwa zwykle 3-4 minuty), przez co przedstawiciele mediów świadomie rezygnują z wybranych formuł. Ujęcie porównawcze wykazało także, iż $w$ tego typu interakcjach sportowcy chętniej niż w pozostałych odmianach rozmowy mówią o przeciwniku, co czynią w sposób elegancki, z zachowaniem zasad grzeczności językowej, także elitarnej, o czym świadczą gratulacje dla drużyny przeciwnej po rozegranym meczu oraz grzecznościowa obudowa wypowiedzi.

W badaniach skupionych na grzeczności $w$ mediach z reguły częściej niż na budowanie partnerstwa komunikacyjnego zwraca się uwagę na brak realizacji podstawowych strategii grzecznościowych5 ${ }^{5}$ Zarówno elementarne, jak i wyrafinowane przejawy etykiety bywają niezauważane, niedoceniane, rozpatrywane jako zachowania niepotrzebne, zbędne lub pełniące jedynie funkcję ornamentu wypowiedzi (por. KıтA, 2016: 196). Wskutek tego więcej niż o grzeczności, także w odniesieniu do przestrzeni medialnej, mówi się o niegrzeczności:

${ }^{5}$ Przykładowo, MARcjanik, omawiając grzeczność w medialnych wypowiedziach dialogowych typu wywiad z politykiem, debata czy niektóre z programów talk show, zwraca uwagę na „obcesowy sposób prowadzenia rozmowy" (2006: 243). Wskazuje także na fakt, iż w interwencjach przedstawicieli mediów nie zauważa się realizacji podstawowych polskich strategii grzecznościowych, takich jak: solidarność z rozmówcą, umniejszanie własnych zasług czy bagatelizowanie przewinień partnera dialogu. 
Nie zauważa się grzeczności, gdy jej reguły są respektowane, ale odstępstwo $w$ tej dziedzinie (zarówno zachowanie ewidentnie niegrzeczne, jak i „zapomnienie” o powiedzeniu odpowiedniej formuły) wywołują niechętną reakcję

KITA, 2005: 126

O tym, iż we współczesnych mediach funkcjonują takie wymiany werbalne, w których uczestnicy dążą do kooperacji i realizują polskie strategie grzecznościowe, świadczą medialne rozmowy ze sportowcami. Nie ma $w$ nich strategii agonistycznych (jak $w$ przypadku programów społeczno-politycznych opartych na dialog $\left.u^{6}\right)$, dziennikarz nie występuje $w$ roli przeciunika - jest za to partnerem oraz pomocnikiem. Popularność medialnych interakcji, których źródłem jest sport, stanowi najlepszy dowód na to, że odbiorcy doceniają przejawy partnerstwa komunikacyjnego w mediach i chętniej wybierają właśnie takie materiały dziennikarskie, w których realizowana jest grzeczność językowa.

\title{
Wykaz skrótów
}

\author{
D - dziennikarz \\ S - siatkarz \\ MP - mikrowywiad pomeczowy \\ WI - wywiad internetowy \\ WR - wywiad radiowy
}

\section{Źródła}

„Kadziu Project" i mikrowywiady pomeczowe [online: https://www.polsatsport.pl/wideo-kategoria/ siatkowka/; data dostępu: 20.10.2020].

„Kierunek Tokio”, Weszło FM [online: https://kierunektokio.pl/category/audycje/; data dostępu: 20.10.2020].

„Prawda Siatki” [online: https://www.youtube.com/c/PrawdaSiatki/videos; data dostępu: 20.10.2020]. „Przy niedzieli o sporcie”, TOK FM [online: https://audycje.tokfm.pl/audycja/28,Przy-Niedzieli-o-Sporcie; data dostępu: 20.10.2020].

„Sam na sam”, kanał internetowy portalu Sport.pl [online: https://www.youtube.com/c/sportpl/ featured; data dostępu: 20.10.2020].

"Warto rozbawiać", kanał internetowy Radia Zet [online: https://www.youtube.com/c/radiozet/videos; data dostępu: 20.10.2020].

${ }^{6}$ Krzysztof GrzegorzewsKı, który analizuje wypowiedzi posła Zbigniewa Ziobry pod względem pragmatycznym, stwierdza: „[...] nie ma miejsca na grzeczność, gdy trzeba atakować przeciwników politycznych. [...] w języku polityki coraz mniej jest grzeczności, a coraz więcej argumentów »ad personam«i zwyczajnej impertynencji" (2012: 38). 
Marcjanik M., 2017: Słownik językowego savoir-vivre'u. Wydawnictwa Uniwersytetu Warszawskiego. Warszawa.

PISAREK W., red., 2006: Słownik terminologii medialnej. Universitas. Kraków.

\section{Literatura}

Anusiewicz J., MARCjAnik M., red., 1992: Język a kultura. T. 6: Polska etykieta językowa. Wydawnictwo „Wiedza o Kulturze”. Wrocław.

GrodzıŃSKı E., 1980: Wypowiedzi performatywne. Z aktualnych zagadnień filozofii języka. Zakład Narodowy im. Ossolińskich. Wrocław.

GRZEGORZEWSKI K., 2012: Retoryczne strategie $w$ autoprezentacji wizerunku politycznego na przykładzie wypowiedzi Zbigniewa Ziobry w przekazie telewizyjnym z lat 2008-2009. „Forum Artis Rhetoricae" 2, s. 31-44.

KACPERSKA B., 2018: Od wywiadu do rozmowy potocznej - o gatunkowych modyfikacjach medialnych rozmów ze sportowcami. „Acta Universitatis Lodziensis. Folia Linguistica” LII, s. 65-80.

KACPERSKA B., 2020: Partnerstwo jako podstawa (wspót)prowadzenia wideobloga sportowego (na przykładzie kanału internetowego „Prawda Siatki”). W: Kalısz A., Tyc E., red.: Partnerstwo $w$ komunikacji. Wydawnictwo Uniwersytetu Śląskiego. Katowice, s. 106-122.

KACPERSKA B., 2021: Współczesne oblicza medialnych rozmów o sporcie. Wydawnictwo Uniwersytetu Łódzkiego. Łódź.

KıтA M., 1998: Wywiad prasowy. Język - gatunek - interakcja. Wydawnictwo Uniwersytetu Śląskiego. Katowice.

KıтA M., 2005: Językowe rytuały grzecznościowe. Wydawnictwo Wyższej Szkoły Zarządzania Marketingowego i Języków Obcych. Katowice.

KitA M., 2012: Medialna moda na dialog. W: KıtA M., Loewe I., red.: Język w mediach. Antologia. Wydawnictwo Uniwersytetu Śląskiego. Katowice, s. 222-237.

KıтA M., 2016: „Grzeczność wszystkim należy, lecz każdemu inna”. O wielości odmian grzeczności językowej. „Postscriptum Polonistyczne” 1 (17), s. 193-212.

Kudra B., 2008: O języku $w$ mediach - uwagi ogólne. W: Bogotє̇BKA B., KudrA A., red.: Wypowiedź dziennikarska. Teoria i praktyka. Wydawnictwo Uniwersytetu Łódzkiego. Łódź, s. 55-61.

Loewe I., 2013: Dyskurs telewizyjny. W: Malinowska E., Nocoń J., Żydek-Bednarczuk U., red.: Style współczesnej polszczyzny. Przewodnik po stylistyce polskiej. Universitas. Kraków, s. 289-311.

Marcjanik M., 2006: ABC grzeczności językowej. W: Bańko M., red.: Polszczyzna na co dzień. Wydawnictwo Naukowe PWN. Warszawa, s. 231-310.

Marcjanik M., 2007: Grzeczność w komunikacji językowej. Wydaunictwo Naukowe PWN. Warszawa.

OżóG K., 1990: Zwroty grzecznościowe współczesnej polszczyzny mówionej (na materiale języka mówionego mieszkańców Krakowa). Państwowe Wydawnictwo Naukowe. Warszawa-Kraków.

Ptaszek G., 2007: Talk show. Szczerość na ekranie? Wydawnictwa Akademickie i Profesjonalne. Warszawa.

Siткошsка K., 2013: Słowo $w$ komunikacji telewizyjnej. Strategie nadawczo-odbiorcze. Wydawnictwo Uniwersytetu Łódzkiego. Łódź. 


\section{$\stackrel{\bullet}{ } \quad$ Beata Kacperska}

N

in SKUDRZYK A., 2007: Normy grzecznościowych zachowań językowych (etykieta językowa, savoir-viure, bon ton, dobre wychowanie, grzeczność językowa). W: Аснтеlıк A., ТАмвоr J., red.: Sztuka czy rzemiosło? Nauczyć Polski i polskiego. Wydawnictwo Gnome. Katowice, s. 105-122.

Sовсzак B., 2006: Wywiad telewizyjny na żywo. Charakterystyka gatunku. Wydawnictwo „Poznańskie Studia Polonistyczne". Poznań.

Stachyra G., 2008: Gatunki audycji w radiu sformatowanym. Wydawnictwo Uniwersytetu Marii Curie-Skłodowskiej. Lublin.

ŚlAwsKa M., 2011: Formy dialogowe $w$ gatunkach prasowych. Katowice [online: https://www.sbc. org.pl/dlibra/show-content/publication/edition/93092?id=93092; data dostępu: 30.10.2020]. 